\title{
Legitimacy Problems in Sharia Compliance Due to Fraud at Islamic Banks in Indonesia
}

\author{
$1^{\text {st }}$ Sucipto $^{1}, 2^{\text {nd }}$ Erwin Saputra Siregar ${ }^{2}, 3^{\text {rd }}$ Mellya Embun Baining $^{3}, 4^{\text {th }}$ Nurjanah $^{4}$, \\ $5^{\text {th }}$ Muhammad Rezki ${ }^{5}$ \\ \{sucipto.djaafar@uinjambi.ac.id ${ }^{1}$, erwinsaputrasiregar@uinjambi.ac.id², \\ mellyaembunbaining@uinjambi.ac.id ${ }^{3}$,jananurjanah167@gmail.com ${ }^{4}$, mrezki93@gmail.com $\left.^{5}\right\}$
}

UIN Sulthan Thaha Saifuddin Jambi ${ }^{1,2,3,4,5}$

\begin{abstract}
This research explains the problem of sharia compliance that fraud cases eroded in 2015 to 2019 in Islamic banks in Indonesia. In comparison, the level of Islamic bank's financial performance in Indonesia, which is categorized in good condition, cannot explain the situation of sharia compliance. This study uses fraud as a dependent variable that results in a decrease in the legitimacy of sharia compliance but not with the financial performance of Islamic banking. Sharia compliance is a matter of legitimacy and a value of Agency where perceived in the variables of this research. At the same time, the independent variables of this study are proxies in the Islamic income ratio, profit sharing ratio, Islamic investment ratio, zakat performance ratio, equitable distribution ratio, and director employee welfare ratio. This study used 11 Islamic commercial banks with a research period from 2015 to 2019 , and the sample used amounted to 41 . The method used is multiple regression analysis of panel data. The results showed that IsIR, PSR, IIR, and DEWR positively affect indications of fraud in Islamic banks in Indonesia.
\end{abstract}

Keywords: Fraud, Sharia Compliance, Agency, Legitimacy, Islamic Bank.

\section{Introduction}

Sharia compliance strategy that is the answer has caused problems in Islamic financial practices[1]. Both sectorally and financially[2]. Sharia compliance often appears in multicontract[3], influencing financial performance[4] a new paradigm to optimize the portfolio of the Islamic finance industry following Islamic sharia[5]. Legitimacy intersects with sharia compliance in the Islamic finance industry, as it is a company of two people with authority[6]. The weak financial industry of Sharia principles and low Sharia compliance can affect the management of the performance of Islamic banks and can provide opportunities for fraud. Sharia compliance problems arise from the role of audit practitioners[7]. The influence of audit quality, on the other hand, affects the competence of practitioners. Unique competencies on the part of the auditor needed to tighten sharia law in addition to old assurance skills and techniques[8]. In addition, the integrity of the auditor and the organization's commitment positively affect fraud preventionssss[9].

The Islamic finance industry in Indonesia is one of them is Islamic banks that experience rapid growth and fraud, which also participates in several cases every year. Financial performance of Islamic banks in Indonesia in the following table: 
Table 1. Financial Performance of Islamic Banks in Indonesia.

\begin{tabular}{|c|c|c|c|c|c|}
\hline Ratio & $\mathbf{2 0 1 5}$ & $\mathbf{2 0 1 6}$ & $\mathbf{2 0 1 7}$ & $\mathbf{2 0 1 8}$ & $\mathbf{2 0 1 9}$ \\
\hline CAR & $15.02 \%$ & $16.63 \%$ & $17.91 \%$ & $20.39 \%$ & $20.59 \%$ \\
\hline ROA & $0.49 \%$ & $0.63 \%$ & $0.62 \%$ & $1.28 \%$ & $1.73 \%$ \\
\hline NPF & $4.84 \%$ & $4.42 \%$ & $4.76 \%$ & $3.26 \%$ & $3.23 \%$ \\
\hline FDR & $88.03 \%$ & $85.99 \%$ & $79.61 \%$ & $78.53 \%$ & $77.91 \%$ \\
\hline BOPO & $97.01 \%$ & $96.23 \%$ & $94.91 \%$ & $89.18 \%$ & $84.45 \%$ \\
\hline
\end{tabular}

Islam strongly rejects all acts of cheating because, in principle, it becomes harm that will harm all parties. With applying Islamic principles, pay great attention to building businesses and companies. So the attitude of a Muslim must be wise in all things; this wise attitude will lead him to success in the world and the hereafter. So it becomes a question whether the principles of Sharia in carrying out activities at Sharia Commercial Bank guarantee to be free from fraud (fraud)? It is not proven by the cases of fraud that occur involving internal Islamic Commercial Banks, namely as follows:

Table 2. Cases of Fraud at Islamic Banks in Indonesia.

\begin{tabular}{|c|l|l|l|}
\hline No. & \multicolumn{1}{|c|}{ Case } & \multicolumn{1}{|c|}{ Person } & Source \\
\hline 1. & $\begin{array}{l}\text { Bank Syariah Mandiri Bogor Branch experienced a } \\
\text { case of distributing fictitious financing amounting } \\
\text { to Rp. 102 billion to 197 fictitious customers } \\
\text { experiencing losses of Rp. 59 billion. }\end{array}$ & $\begin{array}{l}\text { Branch Head and } \\
\text { Officer }\end{array}$ & Kompas.com \\
\hline 2. & $\begin{array}{l}\text { Bank Mega Syariah in 2014, there was a case of } \\
\text { money games packaged in gold investment } \\
\text { products GTIS (Golden Traders Indonesia Syariah) } \\
\text { and GBI (Gold Bullion Indonesia), which offered } \\
\text { to finance 60\% of the total value of a gold } \\
\text { investment. }\end{array}$ & Employee \\
\hline 3. & $\begin{array}{l}\text { Bank Syariah Mandiri in 2018 again allegedly } \\
\text { channeled fictitious financing of Rp. 1.1 Trillion, } \\
\text { which has the potential to cause state losses. }\end{array}$ & Employee & Bisnis.com \\
\hline 4. & $\begin{array}{l}\text { In 2013 fictitious credit case, 3 independent Sharia } \\
\text { Bank officials received Rp 9 Billion }\end{array}$ & Employee & liputan6.com \\
\hline 5. & $\begin{array}{l}\text { In 2019, corruption cases gave credit to PT. } \\
\text { Hastuka Sarana Karya (HSK) in 2014-2016, BJB } \\
\text { Syariah allegedly did not disburse credit by } \\
\text { procedures to include collateral from debtors. }\end{array}$ & Director & bisnis.com \\
\hline 6. & $\begin{array}{l}\text { Bank Jabar Banten Syariah in 2018 was involved in } \\
\text { a case of alleged fictitious credit that harmed the } \\
\text { company worth Rp. 548 Billion }\end{array}$ & Employee & bisnis.com \\
\hline
\end{tabular}

However, in addition to the above performance, the rapid development of Islamic banks is also followed by fraud. The reputation and trust of customers in Islamic banks are essential[10]. Where the reality of fraud that continues to occur and is proven from the following table: 
Table 3. Internal Fraud Cases at Islamic Banks in Indonesia.

\begin{tabular}{|c|c|c|c|c|c|c|}
\hline \multirow{2}{*}{ No. } & \multirow{2}{*}{ Name of Islamic Bank } & \multicolumn{5}{|c|}{ Year } \\
\cline { 3 - 7 } & 2015 & $\mathbf{2 0 1 6}$ & $\mathbf{2 0 1 7}$ & $\mathbf{2 0 1 8}$ & $\mathbf{2 0 1 9}$ \\
\hline 1 & Bank Muamalah & 2 & 84 & 35 & 21 & 26 \\
\hline 2 & Bank Victoria Syariah & 7 & 4 & 1 & 1 & 1 \\
\hline 3 & Bank BRI Syariah & 4 & 6 & 6 & 8 & 10 \\
\hline 4 & Bank Jabar Banten Syariah & 0 & 3 & 9 & 7 & 11 \\
\hline 5 & Bank BNI Syariah & 3 & 6 & 9 & 9 & 9 \\
\hline 6 & Bank Syariah Mandiri & 8 & 25 & 25 & 14 & 10 \\
\hline 7 & Bank Mega Syariah & 1 & 2 & 3 & 3 & 1 \\
\hline 8 & Bank Panin Dubai Syariah & 4 & 2 & 3 & 1 & 1 \\
\hline 9 & Bank Syariah Bukopin & 0 & 0 & 1 & 0 & 2 \\
\hline 10 & Bank BCA Syariah & 0 & 0 & 0 & 0 & 0 \\
\hline 11 & Bank BTPN Syariah & 0 & 0 & 0 & 0 & 0 \\
\hline
\end{tabular}

Although an institution is obliged to carry out sharia principles as its primary foundation, Islamic banks must also be based on favorable laws in Indonesia. This cannot guarantee that fraud will not occur in Islamic banks because it is still shackled with poor management and improper accounting systems[11].

Islamic Bank is a bank that carries out its business activities based on Sharia Principles. While the Sharia Business Unit, called UUS, is a work unit of the head office of a Conventional Commercial Bank that serves as the parent office of the office or unit that carries out business activities based on sharia principles, or a work unit in the branch office of a bank domiciled abroad that carries out conventional business activities that serve as the parent office of sharia maid branch offices and sharia units[12].

This problem proves that Islamic banks have not been free from fraud cases. Financial institutions risk forming fraudulent activities in all forms and ways. Regulation of Central Bank of Indonesia No. 11/ 25 / PBI / 2009 fraud in this condition is something that is an aberration activity or deliberate action done to deceive, manipulate, trick, customers or other parties that are established in the bank area and or use bank facilities to cause the bank, customers or other parties to suffer losses and perpetrators of fraud either directly or indirectly. So that for financial institutions that have a unique character such as sharia-based financial business certainly has a significant effect in its management, thus in need of the principle of the prudence of the perpetrators in the aspect of sharia compliance, namely efforts made as a form of prevention of the possibility of fraud[13]. Hameed et al. research recommends that the Islamic disclosure index (IDI) is needed to meet sharia compliance in Islamic banks based on three indicators of social / environment disclosure, corporate governance, namely sharia compliance and Islamic disclosure[14].

Research conducted by Chapra shows that failure to practice sharia principles by $85 \%$ can make customers move to other banks[15]. Islamic bank compliance is also in line with Islamic principles and ethical values, which can thus create deep organizational commitment among employees[16]. Therefore, the implementation of sharia compliance in Islamic financial institutions becomes a necessity and obligation, especially in Islamic banks in Indonesia, to improve the image and trust of the public in Islamic banks. Algabry's research also proposes that factors that impact sharia audits in the effectiveness of Islamic banks include external and 
internal factors and sharia internal audit structure, processes, and requirements[17]. Research conducted by Fadhistri and Dedik found that sharia compliance with proxy Islamic income ratio partially had no effect in the indication of fraud in Islamic banks. While sharia compliance with proxy profit sharing ratio somewhat negatively affects the movement of Islamic banks' fraud[18].

The question in this study is the legitimacy in sharia compliance whether it results in existing acts of fraud. For this purpose, it is necessary to look at Shariah compliance because, in Islamic banks, these factors are essential. Weak sharia principles and low sharia compliance can affect the management of the performance of Islamic banks and can provide opportunities for fraud. Rashid et al.'s research show that better sharia compliance for Islamic banks requires the role of audit practitioners. The competence of practitioners becomes one of the essential factors that affect the quality of sharia audits. Different contracts, financial arrangements, and transactions require unique competencies on the part of the auditor, i.e., tightening sharia law in addition to old assurance skills and techniques[8]. Rifai's research also found that auditor organizational commitment and integrity positively affect fraud prevention[9].

Juridically, the company's ownership, the financial industry shareholders (principal), but who operates it is the Manager (agent). One goal is that the company can continue to maximize return and dividend investment. In comparison, the Manager maximizes the company's usefulness in meeting personal needs related to work and additional income). Stewardship theory is defined as a situation in which the stewards (managers) have no personal interest but are more concerned with the interests of the principal (owner). This stewardship theory assumes a strong relationship between organizational success and company performance. The fun utility will maximize the owner's expectations because stewards achieve organizational goals rather than individual goals. The implications of stewardship theory in this study if Islamic income increases, then the act of fraud will decrease because Islamic income by sharia principles is one way to maintain the public's trust to choose Sharia Bank. As well in the management of Islamic investment operations must be by sharia principles. People will certainly lose the privileges they seek in Islamic banking services without compliance with Sharia principles, which is no different from conventional banking, so that it will affect their decision to choose or continue to use the services provided by Sharia Bank. So sharia compliance is one way to maintain the trust of the community[19]. Because it is related to the separation of control and ownership, the impact of information asymmetry is contrary to the objectives of the Institution[20]. Adam Smith, in 1776 realized that the weakness of modern companies was due to cheating and abuse[11]. Maintaining the trust of Sharia Bank customers aims to increase revenue and decrease fraud. Adherence to sharia principles in Islamic banking services becomes a differentiator with conventional banking and rational choices.

Sharia Enterprise theory is an accounting theory of equity or ownership of an organization or entity. Among these existing theories, which are seen as aligned with the Islamic point of view, is entity theory-enterprise theory as a theoretical concept of Islamic accounting. Enterprise theory has a broader understanding than entity theory because enterprise theory is more of a social theory whose orientation focuses on aspects of sociology and answers responsibility[21]. While the financial industry has agents in the relationship between the owner and the moral management of partnerships between one or more people, where the owner of the fund employs another person to provide a service and then delegates the authority and responsibility of decision-making to the management and the owner as stipulated in the employment contract or mutual agreement this is an agency relationship, the act of cheating is an asymmetry between information owned by management that is used to 
take advantage in gaining an advantage for himself or others. This can cause excitement for owners and companies so that agency problems arise. The impact of information asymmetry on the relationship between actors' interests is "hidden information," which refers to the Agency's fact of pursuing its own goals, even if it conflicts with the Agency's objectives.

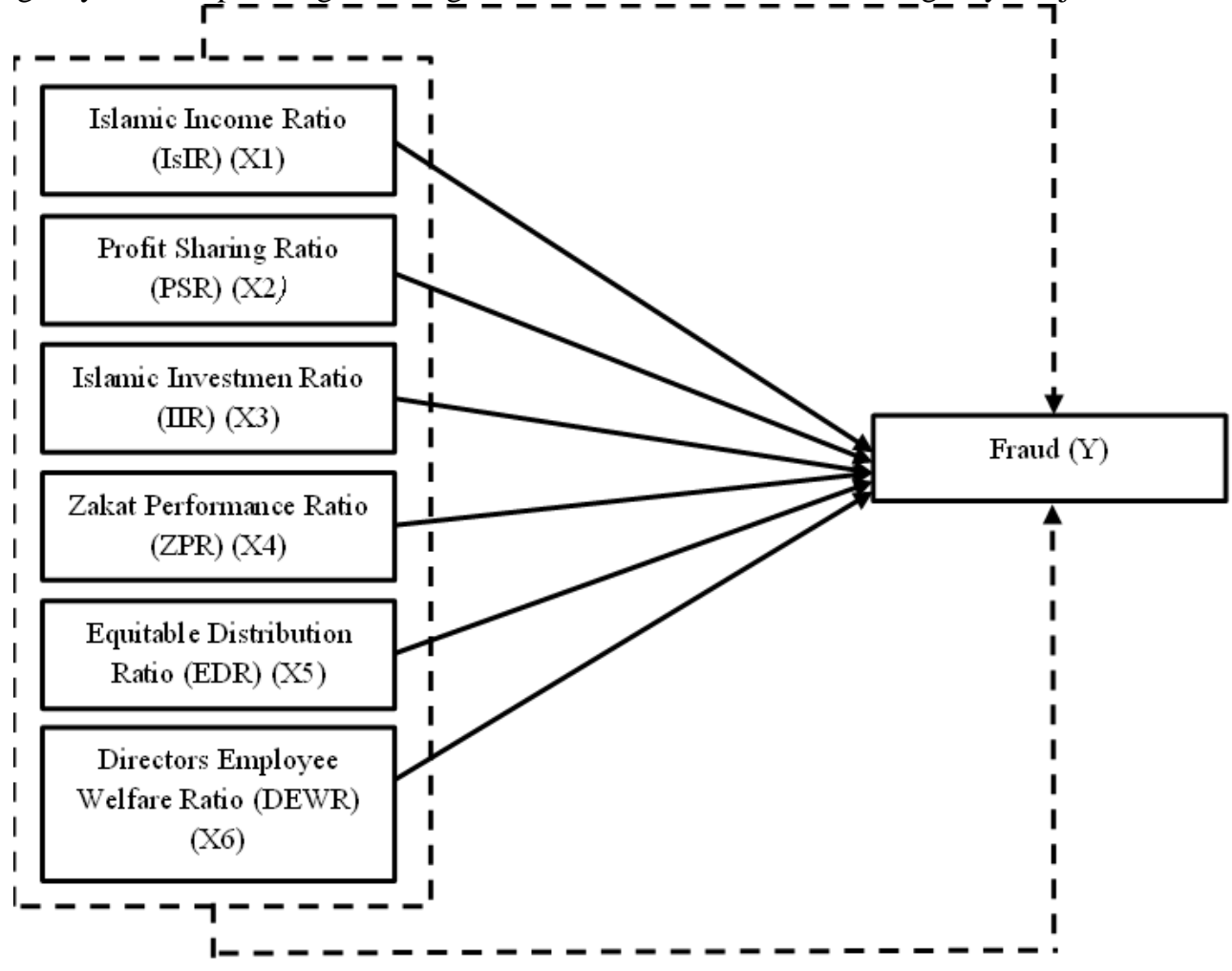

Fig. 1. Framework of Thought.

Based on figure 1 above can be made research hypotheses as follows:

1. IsIR variables, PSR variables, IIR variables, ZPR variables, EDR variables, and DEWR variables on Fraud in Islamic Commercial Banks in Indonesia period 2015 to 2019 partially.

2. IsIR variables, PSR variables, IIR variables, ZPR variables, EDR variables, and DEWR variables on Fraud in Islamic Commercial Banks in Indonesia period 2015 to 2019 simultaneously.

\section{Methodology}

The study used quantitative methods with secondary data types. The population used is all Islamic banks registered with the Financial Services Authority for 2015 to 2019, which amounted to 14 Islamic banks in Indonesia. Sample selection using purposive sampling, so 
that according to the criteria is as many as 11 Islamic banks with the calculation of the number of research samples that are $11 \times 5=55$ sample data.

Multiple linear regression analysis methods are made an option in analyzing using panel data in this study. A multiple linear regression analysis model is a dependent variable (variable $\mathrm{Y}$ ) associated with two independent variables (variable X). In general, the forms of regression equations in this study are as follows:

$$
\mathrm{Y}=\mathrm{a}+\mathrm{b}_{1} \mathrm{X}_{1}+\mathrm{b}_{2} \mathrm{X}_{2}+\mathrm{b}_{3} \mathrm{X}_{3}+\mathrm{b}_{4} \mathrm{X}_{4}+\mathrm{b}_{5} \mathrm{X}_{5}+\mathrm{b}_{6} \mathrm{X}_{6}+\mathrm{e}
$$

Furthermore, the equation is transformed in the form of a double logarithm equation which in this study is as follows:

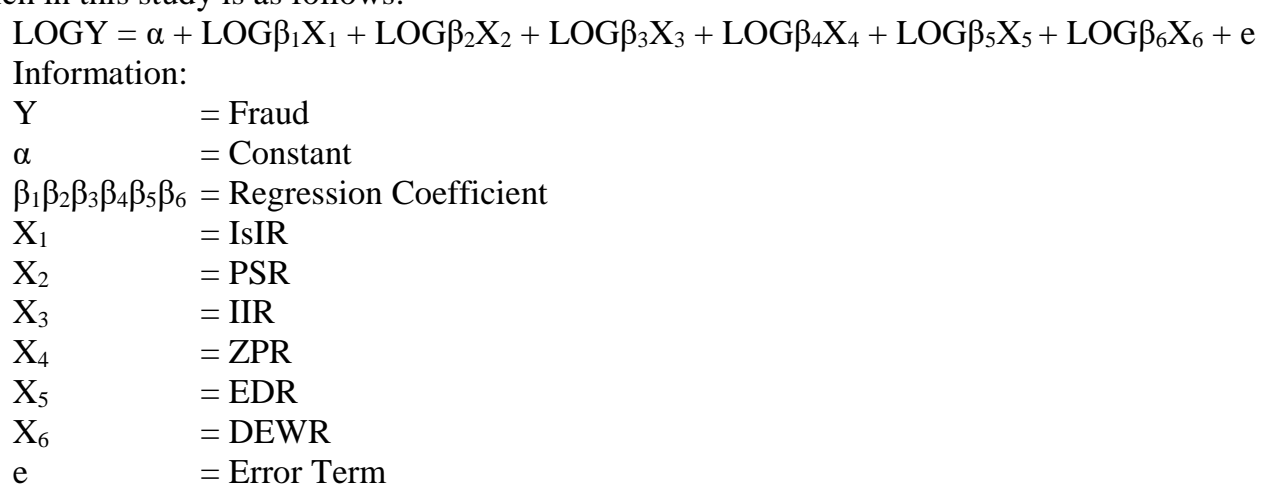

\section{Result and Discussion}

The regression that uses panel data has a combination of characteristics, namely data consisting of several objects (cross-section) and covering time (time series). Panel data that has been collected, aggregated using the fixed-effect method whose results can be seen in Table 4 below:

Table 4. Panel Data Regression Results.

\begin{tabular}{|c|c|c|c|c|}
\hline Variable & Coefficient & Std. Error & t-Statistic & Prob. \\
\hline C & 1,103709 & 1,822643 & 0,605554 & 0,5513 \\
\hline LOGISIR & 216,9373 & 93,83451 & 2,311914 & 0,0310 \\
\hline LOGPSR & 0,692286 & 0,253300 & 2,733068 & 0,0125 \\
\hline LOGIIR & 2,382870 & 1,044834 & 2,280620 & 0,0331 \\
\hline LOGZPR & 0,297259 & 0,166813 & 1,781986 & 0,0892 \\
\hline LOGEDR & 0,025317 & 0,078475 & 0,322607 & 0,7502 \\
\hline LOGDEWR & 1,322156 & 0,236841 & 5,582471 & 0,0000 \\
\hline R-square & 0,887858 & Mean dependent var & 2.123322 \\
\hline Adjusted R-squared & 0.818437 & \multicolumn{2}{|c|}{ S.D. dependent var } & 1.486580 \\
\hline S.E. of regression & 0.560490 & Sum squared resid & 6.597135 \\
\hline F-statistic & 12.78946 & \multicolumn{4}{|c|}{ Durbin-Watson stat } & 2.049031 \\
\hline Prob (F-statistic) & 0.000000 & \multicolumn{4}{|l}{} \\
\hline
\end{tabular}


Based on table 4, significant test results of individual parameters above are as follows:

1) The Effect of IsIR on Fraud

The variable IsIR probability value (prob) of 0.0310 is smaller than the significance level $(\alpha)$ of 0.05 with a calculated value smaller than the table $(2,311>1.701)$, so $\mathrm{H}_{\mathrm{a}}$ is accepted.

The results of this study are in line with research from Raharjanti and Muharrami, which stated that the ratio of Islamic income has a positive influence on internal fraud. In practice, all Islamic banks have a high Islamic income ratio. Although it has a high Islamic income ratio, internal fraud within Islamic banks also occurs[22]. This can be because income is an account that is vulnerable to manipulation and theft. This incident proved that the most common fraud technique is improper income recognition[23].

2) The Effect of PSR on Fraud

The Variable PSR with a probability value (prob) of 0.0125 which is smaller than the significance level $(\alpha)$ of 0.05 with a calculated $t$ value more significant than the table $t(2,733$ $>1.701)$ so that Ha is accepted.

The results obtained in this study, namely the Profit-Sharing Ratio, have a positive effect on fraud; it can be interpreted that the greater the Profit-Sharing Ratio indicates that, the more transactions with the principle of profit-sharing carried out by Islamic Banks, the positive effect of PSR on fraud is assumed to be the increase in fraud cases that occur. This can be due to the lack of implementation of the profit-sharing principle following sharia principles and the transparency of managers to funds entrusted by the fund owner to cause fraud.

3) The Effect of IIR on Fraud

The variable IIR probability value (prob) of 0.0331 is smaller than the significance level $(\alpha)$ of 0.05 with the value of $t$ calculated greater than $t$ table $(2,280>1.701)$, so $\mathrm{Ha}$ is accepted.

The results obtained in this study, namely the Islamic Investment Ratio, have a positive effect on fraud; it can be interpreted that the higher the IIR indicates an increase in fraud cases that occur in Islamic banks. The IIR ratio suggests that the investment has been made following sharia provisions. However, in reality, there is still much cheating going on. This can be because Islamic bank assets are vulnerable to manipulation and theft. The vulnerability of manipulation and theft provides an excellent opportunity for employees to commit fraud.

4) The Effect of ZPR on Fraud

The variable ZPR of probability values (prob) of 0.0892 is greater than the significance level $(\alpha)$ of 0.05 , so Ha is rejected.

The results obtained in this study are that there is no influence of Zakat Performance Ratio on Fraud; it can be interpreted that this ratio cannot measure the impact of fraud on Islamic Banks, judging from Basam and Chistoper research that states the primary purpose of Sharia Bank established is to uphold Islamic economic principles that create community economic justice through zakat. The obligation to pay zakat following sharia rules, in general, is $2.5 \%$ of net assets[14]. Zakat becomes a top priority in financial statements because it is corporate social accountability to the community.

5) The Effect of EDR on Fraud

The variable EDR probability value (prob) of 0.7502 , which is greater than the significance level $(\alpha)$ of 0.05 with the value of $t$ calculated smaller than $t$ table $(0.322<$ 1.701), so Ha is rejected.

The results obtained in this study that there is no equitable distribution ratio on fraud can be interpreted this ratio cannot measure the effect of fraud on Islamic banks. Islamic banks have not distributed too much of their income to qardh activities and donations. So that the 
chances of cheating will be small because the movement is still minimal so that fraud will be easily detected.

6) The Effect of DEWR on Fraud

The variable DEWR probability value (prob) of 0.0000 , which is smaller than the significance level $(\alpha)$ of 0.05 with a calculated $t$ value more significant than the table $t(5,582$ $>1.701)$, so that Ha is accepted.English translation.

The results obtained in this study, namely the director's employee welfare ratio, have a positive effect on fraud, meaning that the increase in salaries and compensation of directors and labor costs positively affect the level of fraud that can be caused by the imbalance of labor costs with the number of existing workers. Similarly, the increase in salaries and compensation of directors is not balanced with increases in wages and employee compensation. It can result in a negative impact that allows the emergence of fraudulent acts.

English translation. Islam guides those who employ others that the principle of wages must include two things, namely fair and sufficient. Islamic banks should uphold the principle of justice in every policy. Fairness and eligibility will make the employee calm and concentrate on his work, so discipline, cooperation, and morale will increase.

\section{Conclusion}

Based on the description of the results of the analysis, hypothesis testing using regression panel data and discussion of research results can be concluded as follows:

a. Variables of IsIR, PSR, IIR, ZPR, EDR, and DEWR together (simultaneously) affect fraud.

b. IsIR variable has a significant and positive effect on fraud.

c. PSR variable has a significant and positive effect on fraud.

d. IIR variable has a significant and positive effect on fraud.

e. ZPR variable does not affect fraud.

f. EDR variable does not affect fraud.

g. DPWR variable has a significant and positive effect on fraud.

\section{References}

[1] L. Rethel, "Whose Legitimacy? Islamic Finance and the Global Financial Order," Rev. Int. Polit. Econ., vol. 18, no. 1, pp. 75-98, 2011.

[2] Khatkhatay, M. Husain, and S. Nisar, "Shariah Compliant Equity Investments: An Assessment of Current Screening Norms," Islam. Econ. Stud., vol. 15, no. 1, 2007.

[3] M. Maksum, "The Sharia Compliance of Islamic Multi-Contract in Islamic Banking," 2018.

[4] Djuwita, Diana, N. E. Setiowat, and U. Kulsum, "The Influence of Sharia Compliance and Sharia Corporate Governance on the Financial Performance of Sharia Commercial Banks," Al-Amwal J.

Ekon. Dan Perbank. Syari'ah, vol. 11, no. 2, p. 205, 2019.

[5] Widiyanti, Marlina, and M. Jusoh, "A New Paradigm and New Strategies for Shariah-Compliant Portfolio Optimization: How to Practice in Indonesia," 2012.

[6] Jensen, C. Michael, and H. M. William, "Theory of the Firm: Managerial Behavior, Agency

Costs and Ownership Structure," J. financ. econ., vol. 3, no. 2, p. 305, 1976.

[7] S. Subramanian, "Stewardship Theory of Corporate Governance and Value System: The Case of a Family-Owned Business Group in India," Indian J. Corp. Gov., vol. 11, no. 1, pp. 88-102, 2018.

[8] Rashid, Abdul, and M. Saarim Ghazi, "Factors Affecting Sharī 'ah Audit Quality in Islamic

Banking Institutions of Pakistan: A Theoretical Framework," Islam. Econ. Stud., 2021. 
[9] M. H. Rifai and A. W. Mardijuwono, "Relationship between Auditor Integrity and Organizational Commitment to Fraud Prevention," Asian J. Account. Res., 2020.

[10] Falikhatun and Y. U. Assegaf, "Bank Syariah Di Indonesia: Ketaatan Pada Prinsip- Prinsip Syariah Dan Kesehatan Finansial," in Conference in Business, Accounting, And Management (CBAM), 2020, p. 245.

[11] A. Mujib, "Sharia Fraud Model: The Fraud in The Circle of Faith," in UNEJ E-Proceeding, 2018, p. 275.

[12] Harahap, S. Safri, and M. Yusuf, Akuntansi Perbankan Syariah. LPFE Usakti, 2010.

[13] Sula, A. Emilia, and M. Nizarul Alim, "Pengawasan, Strategi Anti Fraud, Dan Audit Kepatuhan Syariah Sebagai Upaya Fraud Preventive Pada Lembaga Keuangan Syariah," J. Audit. Financ.

Forensic Account., vol. 2, no. 2, pp. 91-100, 2014.

[14] Asrori, "Kepatuhan Bank Syariah Terhadap Prinsip Shari'ah,” J. Din. Akuntasi, vol. 3.

[15] Wardayanti and S. Maria, "Implikasi Shariah Governance Terhadap Reputasi Dan Kepercayaan Bank Syariah,” Walisongo J. Penelit. Sos. Keagamaan, vol. 19, no. 1, pp. 1-24, 2011.

[16] F. Natigor Nasution and A. Rafiki, "Islamic Work Ethics, Organizational Commitment and Job Satisfaction of Islamic Banks in Indonesia," RAUSP Manag. J., vol. 55, pp. 195-205, 2020.

[17] L. Algabry, "Conceptual Framework of Internal Sharī'ah Audit Effectiveness Factors in Islamic Banks," ISRA Int. J. Islam. Financ., 2020.

[18] Fadhistri, K. Amanna, and D. Nur Triyanto, "Pengaruh Islamic Corporate Governance Dan Sharia Compliance Terhadap Indikasi Terjadinya Fraud Pada Bank Umum Syariah Di Indonesia (Studi Empiris Pada Bank Umum Syariah Periode 2014-2017)," 2019.

[19] U. Hasanah, "Kepatuhan Prinsip-Prinsip Syariah Dan Islamic Corporate Governance Terhadap Kesehatan Finansial Pada Bank Umum Syariah,” UNIVERSITAS NEGERI SEMARANG, 2015.

[20] Panda, Brahmadev, and N. M. Leepsa, "Agency Theory: Review of Theory and Evidence on Problems and Perspectives,” Indian J. Corp. Gov., vol. 10, no. 1, pp. 74-95, 2017.

[21] Setiabudi, Y. Hendry, and I. Triyuwono, Akuntansi Ekuitas Dalam Narasi Kapitalisme, Sosialisme, Dan Islam. 2002.

[22] Raharjanti, I. Ayu, and R. S. Muharrami, "The Effect of Good Corporate Governance and Islamicity Financial Performance Index of Internal Fraud Sharia Banking Period 2014-2017,” J. Bus. Manag. Rev., vol. 1, no. 1, pp. 61-75, 2020.

[23] Najib, Haifa, and Rini, "Sharia Compliance, Islamic Corporate Governance Dan Fraud Pada Bank Syariah," J. Akunt. Dan Keuang. Islam, vol. 4, no. 2, p. 131, 2016. 